\title{
The Effectiveness of PBL Models Based on Google Meet on the Ability of Mathematical Problem Solving
}

\section{Danis Safitri' ${ }^{1}$ Nurafni2}

1,2 Universitas Muhammadiyah Prof Dr. Hamka, Jakarta, Indonesia

\section{A R T I C L E I N F O}

Article history:

Received March 08, 2021

Revised March 11, 2021

Accepted April 30, 2021

Available online May 25, 2021

Kata Kunci:

PBL, Kemampuan Pemecahan Masalah Matematika

Keywords:

PBL, Mathematics Problem Solving Ability

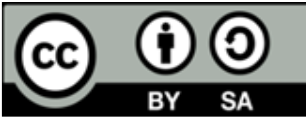

This is an open access article under the CC BY-SA license.

Copyright (C) 2021 by Author. Published by Universitas Pendidikan Ganesha.

\begin{abstract}
A B S T RA K
Pandemi Covid-19 berpengaruh besar terhadap berbagai sektor, termasuk sektor pendidikan. Hal ini membuat pendidik melakukan suatu inovasi dalam model pembelajaran, yaitu mengkombinasikan model PBL berbasis google meet. Tujuan dari penelitian ini yaitu untuk menganalisis ada atau tidaknya pengaruh model PBL berbasis google meet terhadap kemampuan pemecahan masalah matematika di kelas IV selama PJJ. Jenis penelitian yang digunakan oleh peneliti yaitu kuantitatif. Dengan desain penelitian quasi eksperiment dengan posttest only group desgin. Subjek dalam penelitian ini adalah siswa kelas IV sebanyak 64 siswa. Teknik pengumpulan data wawancara dan tes. Sedangkan instrument penelitian berupa soal posttest. Analisis data yang digunakan adalah analisis deskriptif, uji homogenitas, uji normalitas, uji hipotesis (uji-t), dan uji effect size. Hasil penelitian menunjukan bahwa nilai rata-rata posttest kelas eksperimen sebesar 76,25 lebih tinggi dari pada kelas kontrol yaitu 62,18. Pada uji hipotesis melalui uji-t diperoleh nilai sig 0,47 yang mana nilai tersebut lebih kecil dari $\alpha=0,05$ sehingga $\mathrm{HO}$ ditolak dan $\mathrm{H} 1$ diterima. Artinya terdapat pengaruh penggunaan model PBL berbasis google meet terhadap kemampuan pemecahan masalah matematika pada kelas IV. Jadi, penggunaan model PBL berbasis google meet ini dapat diterapkan pada pembelajaran saat daring.
\end{abstract}

\section{A B S T R A C T}

Pandemic Covid-19 has a big influence on various sectors, including the education sector. This makes educators make an innovation in the learning model, which combines a model of PBL-based google meet. The purpose of this study is to analyze the presence or absence of the influence of the PBL models based on google meets on the ability of mathematical problem-solving in grade IV during distance learning. The type of research used by researchers, namely quantitative. With research design a quasi-experiment with posttest only group design. Subjects in this study were students of class IV as many as 64 students. Data collection techniques interviews and tests. While the research instrument is in the form of a posttest. Data analysis used is descriptive analysis, a test of homogeneity, normality test, hypothesis test (t-test), and test the effect size. The results showed that the average value of the posttest experimental class of 76,25 higher than the control class that is 62,18 . In hypothesis testing via t-test obtained the value of sig 0.47 that where the value is smaller than $\alpha=0.05$ so that $\mathrm{HO}$ is rejected and $\mathrm{H} 1$ is accepted. This means that there is an influence of the use of PBL models based on google meet on the ability of mathematical problem-solving in grade IV. So, the use of PBL models based on google meet can be applied to learning online.

\section{INTRODUCTION}

Pandemic Covid-19 has a big influence on various sectors, including the education sector. some of the activities that gather a lot of people like activities such as seminars, workshops, conferences and other events postponed and even cancelled (Mishra et al., 2020; Oyedotun, 2020; Patricia, 2020; Sahu, 2020). Even learning that first face-to-face to be replaced with online learning, the online learning process of learning can be done and still maintaining the safety of learners and educators (Dong et al., 2020; Hashim et al., 2020; Rahayu, 2021). Online learning is learning carried out with the help of the internet both synchronously and asynchronously, which provide the opportunity to the students ' interact with learning resources teacher/environment as well as their peers (Dong et al., 2020). The presence of online learning 
allows the learners to share their opinions and learn more independently without any limits of time and space is more flexible (Hwang et al., 2020; Kkese, 2020; Lage-Cala et al., 2020). Online learning is online learning that really needs the ability of educators and learners because the ability in using the technology will be of great help to create a more conducive learning atmosphere, thus forming a social interaction the better (Andel et al., 2020). In addition to the skills course, online learning should also pay attention to the financial condition of the learners and the facilities and infrastructure that support online learning (Rusli et al., 2020). Although the learning is done online, students are still required to have the ability to break the problem. In the process of solving the problems, students are allowed to play an active role in learning, searching, and find their own information or data to be processed into the concepts, principles, and conclusions (Rahmiati \& Fahrurrozi, 2016). Learners can be said to have the problem-solving ability if learners can perform several stages of the indicators of problem-solving skills such as problem-solving ability is very important in school mathematics, without the ability to solve problems, the usefulness and power of mathematical ideas, knowledge, and skills are very limited (Mariani \& Susanti, 2019; Rambe \& Afri, 2020). As for problem-solving can be used to help students in improving the ability to analyze and positive effect on student learning outcomes (Cahyani \& Setyawati, 2016; Nurliawaty et al., 2017).

However, it is not forever learning online/online such a positive impact, online learning has an impact on the change of attitude insulation social, lack of interactivity, participation and limitations of feedback (Mulyanti et al., 2020; Rosmiati \& Lestari, 2021; Suhery et al., 2020). Less unprepared parents in the face of online learning, online learning does not have the atmosphere of the formal as traditional learning, the online learning does not occur social interaction fellow learners (Dong et al., 2020b). Many kids don't do online learning, doing other activities in addition to learning such as playing games, social media and more much-watching youtube as well as other activities that indicate the presence of addiction "devices" (Liu et al., 2020; Rahmawati \& Latifah, 2020; Samaha \& Hawi, 2016). This condition is in line with the results of the preliminary analysis which stated that online learning is not effective for students in SDN Rawabadak Utara 11 Pagi. because a lot of students do not understand the material well, especially in the subjects of mathematics. Students expressed less capability in solving problem-solving. It is characterized by the results of student learning that is less than the KKM in the previous lesson. During the period of the pandemic, this math lesson is done online and only assisted the google classroom course where students are only given the task in the absence of an explanation of material in advance of such teachers that led the student is not able to understand the task in solving the problem. As well as, problem-solving abilities in Indonesia is still relatively low. It is seen from the results of the International Mathematics Competence, PISA (Program for International Student Assessment) concluded that the quality of students in mathematics learning in Indonesia is still ranked 64 of the 72 participating countries. Based on the acquisition of data that Indonesian students are very good when working on problems of the theory and rote, but when working on problems that have aspects such as high levels of problems of reasoning and solving problems they are having trouble solving it (N. Hidayati \& Permana, 2019). In the process of learning mathematics in schools in Indonesia are not yet fully emphasize the problems of solving the problem so that mathematics is often considered boring for the learners because of the high level of difficulty and in general mathematics teachers taught with lecture method this leads to less active learners in the learning so that problem-solving ability in the lesson is very difficult to even many students who do not understand about the lesson that is given and described by teachers so that the learning process such as this is less to provide an opportunity in solving the problem. (Suhartono, 2018; Usman \& Afriansyah, 2017). And another problem is with the granting of a problem that is too complicated will cause learners to be frustrated and do not want to learn. This condition will greatly affect the results of the study will be the hedge against the quality of Education output.

One of the efforts to improve the ability to solve the problem is the teachers need to determine the model of the learning tools in learning mathematics online. The addition of a learning model by the need to optimize the quality and learning ability of learners to achieve the categories are good in learning (Herliandry et al., 2020; E. P. Sari \& Sukardi, 2020). We need a model that is flexible and can be used in online learning (Johan Wicaksana et al., 2021; Muhammad et al., 2020). One of the models that can be used to develop the problem-solving skills of the students, a model that can be used is the model of Problem Based Learning (PBL) (Ruchaedi \& Baehaki, 2016; Safithri et al., 2021). PBL is a learning model that engages students in solving a problem through the stages of the scientific method so that students can learn the knowledge related to the problem and at the same time have the skills to find a solution for a real problem (Nofziarni et al., 2019; Shofiyah \& Wulandari, 2018). Not only that PBL also equips students with the knowledge, increase problem-solving skills, the skills of critical and creativity, communication skills, teamwork, adaptability to change, and self-evaluation (Anazifa \& Djukri, 2017). By applying the model of PBL in online learning in mathematics assisted application will strengthen the problem-solving 
skills and independent character of the students so that students can formulate, solve, and interpret mathematics in a variety of contexts (N. Hidayati \& Permana, 2019; Tambunan et al., 2018).

Some of the research that has been there previously conducted on the students of class XI based on the results of the study shows that the model PBL effect on the activity and the value of the students at the time of online learning (Djunaedy, 2020) where the value of students using PBL models online is higher than the value of the students who did not use the model of PBL. Then further research that is in the class of $\mathrm{X}$ to show that the use of PBL models in the setting of online learning is suggested as a learning model for problem-solving (Santika et al., 2020). Then in the eighth grade, students showed the application of the PBL models online may increase the activeness and learning achievement of students. (Yana et al., 2021). Therefore the researchers combined model PBL based on google meet. Google meet is one of the applications or software vicon developed by Google that can be used for the process of learning online (Fanny Ahmad Fauzi \& Puji Lestari, 2020). Because at this time the use of technology has a great contribution in the world of education with the assisted application google meet in online learning is intended to allow teachers and students can still interact despite being in different places (Dewi, Pratisia, 2021; Firman \& Rahman, 2020). The purpose of this study is to analyze whether or not there is a significant influence on the model of the PBL-based google meet on the ability of mathematical problemsolving in grade IV for distance learning in SDN Rawabadak Utara 11 Pagi. This research was conducted with the hope of being able to change the learning process for distance-learning where this process consists of a combination of information, interaction, and communication and reduce some of the negative consequences of teaching fully online, such as learning difficulties in mathematics, especially in improving the problem-solving ability of mathematics students. To foster a positive attitude towards mathematics to achieve competence and learning outcomes in mathematics are better.

\section{METHOD}

The type of research used by researchers, namely quantitative. The research design is quasiexperimental or experimental facades where the design is to have a control group, but can not be fully functional to control the variables-outside variables that affect the execution of the experiment (K. A. Sari et al., 2017). And use the type of post-test-only control design, in which in full compliance on one variable only. The research was conducted at SDN Rawabadak Utara 11 Pagi which is located at Jl. Rawa Badak Utara No.37, RT.6/RW.5, Rawabadak Utara, Kec. Koja, Kota Jkt Utara, Daerah khusus Ibukota Jakarta 14230 which discusses whether there is an influence or not PBL models of the problem-solving ability of mathematics at the fourth-grade students of SDN Rawabadak Utara 11 Pagi. The population in this research is the whole students of class IV SDN Rawabadak Utara Pagi Jakarta Utara which amounted to 64 students. The sample used in this study using two classes, namely class IV-A and IV-B, which respectively amounted to 32 students. The technique used in sampling this research is the nonprobability technique with samples saturated sampling customized with research.

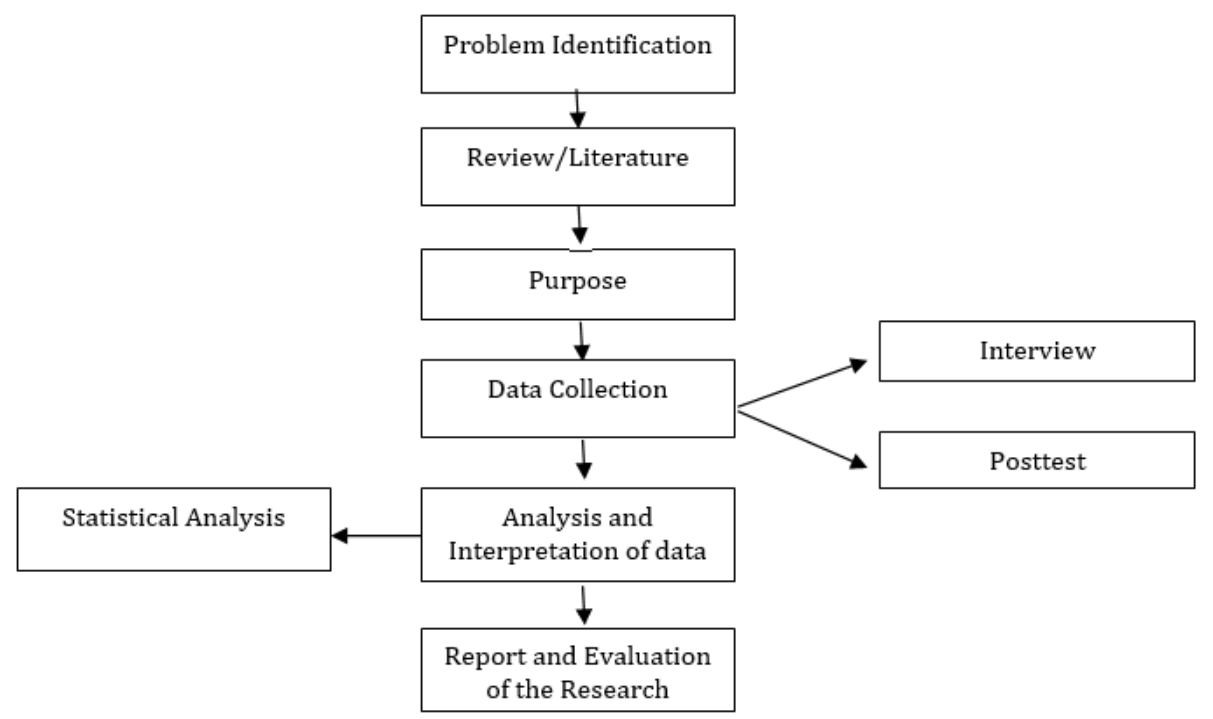

Gambar 1. Research Design Quantitative ( Creswell) 
Data collection methods used include 1) Interview, the goal is to get the information about how the process of learning for distance learning and students responses when using the model of PBL-based google meet; 2) the Posttest, contains 12 essay questions to determine the benchmark level of understanding of learners in mastering the material that has been given by using two different models. There are several criteria and indicators in the test of problem-solving skills to determine the knowledge of students in solving word problems. Instrument scoring based on the steps workmanship students and criteria problem-solving ability (Amam, 2017). Lattice Intrument shown in tables 1 and 2.

Table 1. Instrument Scoring Test problem-Solving Ability

\begin{tabular}{|c|c|c|}
\hline Aspects Assessed & The Reaction To The Question Or Problem & Score \\
\hline \multirow{3}{*}{$\begin{array}{l}\text { Understand the } \\
\text { problem }\end{array}$} & Do not understand question/no answer & 0 \\
\hline & One of interpreting the most about and ignore conditions about & 1 \\
\hline & Understand the problem more & 2 \\
\hline \multirow[t]{5}{*}{ Make a plan } & No plan/make a plan that is not relevant & 0 \\
\hline & Make a plan solving improper & 1 \\
\hline & Create a plan that's right but wrong in result/no result & 2 \\
\hline & Make a plan right but is not yet complete & 3 \\
\hline & $\begin{array}{l}\text { Make a plan according to the procedure and lead to the correct } \\
\text { solution }\end{array}$ & 4 \\
\hline Finish & No resolution & 0 \\
\hline \multirow[t]{4}{*}{ problems } & There is a settlement but the procedure is not clear & 1 \\
\hline & Perform the procedure and produce the correct answer & 2 \\
\hline & $\begin{array}{l}\text { Perform the correct procedure and may produce the correct } \\
\text { answer but calculate }\end{array}$ & 3 \\
\hline & Do the process and the results really & 4 \\
\hline \multirow[t]{4}{*}{ Check back } & No examination answers & 0 \\
\hline & No examination but less complete & 1 \\
\hline & Checks are made to see the truth of the process & 2 \\
\hline & score & 12 \\
\hline
\end{tabular}

As for the Instruments of the questions that will be used in the study as follows.

Table 2. Test instruments

\begin{tabular}{|c|c|c|c|c|c|}
\hline $\begin{array}{c}\text { Basic } \\
\text { Competence }\end{array}$ & $\begin{array}{l}\text { Indicator Problem } \\
\text { Solving Ability }\end{array}$ & Indicator Question & Level & $\begin{array}{c}\text { The } \\
\text { form of } \\
\text { test }\end{array}$ & $\begin{array}{c}\text { number of } \\
\text { questions }\end{array}$ \\
\hline $\begin{array}{l}\text { 3.9 Explain and } \\
\text { determine the } \\
\text { circumference } \\
\text { and area of a } \\
\text { square, }\end{array}$ & $\begin{array}{l}\text { 1. Understand the } \\
\text { problem } \\
\text { 2. Make A Plan } \\
\text { 3. Solve the } \\
\text { problem }\end{array}$ & $\begin{array}{l}\text { Presented in the form of } \\
\text { story problems, learners } \\
\text { can solve problems } \\
\text { related to the perimeter } \\
\text { and area of a square }\end{array}$ & $C 4$ & Essay & $1,2,3,4$ \\
\hline $\begin{array}{l}\text { rectangle, and } \\
\text { triangle } \\
4.9 \text { Solve } \\
\text { problems } \\
\text { related to }\end{array}$ & $\begin{array}{l}\text { 4. Re-examine the } \\
\text { process and the } \\
\text { results }\end{array}$ & $\begin{array}{l}\text { Presented in the form of } \\
\text { story problems, learners } \\
\text { can solve problems } \\
\text { related to perimeter and } \\
\text { area of a rectangle }\end{array}$ & $C 4$ & Essay & $5,6,7,8$ \\
\hline $\begin{array}{l}\text { perimeter and } \\
\text { area of a square, } \\
\text { rectangle, and } \\
\text { triangle }\end{array}$ & & $\begin{array}{l}\text { Presented in the form of } \\
\text { story problems, learners } \\
\text { can solve problems } \\
\text { related to perimeter and } \\
\text { area of triangle }\end{array}$ & $C 4$ & Essay & $9,10,11,12$ \\
\hline
\end{tabular}

Before being used for research about the user was first tested in different schools but in the same level so knowing how worthy and valid questions for research. Test the validity of the instrument about the user is the formula of product-moment (Bertan et al., 2016). The formula of product-moment was used to calculate the validation of the grain problem because the instrument used the essay form. Validity test is done to compare the results of the calculation $r_{x y}$ with $r$ table at the 0.05 level of significance by 
setting the first degree of freedom(df) or degrees of freedom, namely $\mathrm{df}=\mathrm{n}-2$ with the criteria of validity are shown in Table 3.

Table 3. Criteria Validity

\begin{tabular}{cc}
\hline Range & Description \\
\hline $0,8-1,000$ & Very strong \\
$0,6-0,799$ & Strong \\
$0,4-0,599$ & Medium \\
$0,2-0,399$ & Weak \\
\hline
\end{tabular}

After the validity of the test, the next step is to do the measurement reliability. The formula used is Alpha Cronbach (Yusup, 2018). The value of $r$ obtained from the results of the calculations are then compared with the price of $\mathrm{r}_{\text {table }}$ with $\mathrm{a}=0.05$ and $\mathrm{df}=\mathrm{N}-2$ ( $\mathrm{N}=$ number of students). and $\mathrm{r}_{\text {count }}>\mathrm{r}$ table, then the point about reliable. Interpretation of the value of the $r_{i}$ shown in table 4. Methods of data analysis used are descriptive analysis, normality test, homogeneity test and parametric statistics. Statistical analysis parametric itself is carried out to test the hypothesis through a t-Test with the provisions of the collected data is normally distributed and the data are homogeneous with the assisted program SPSS 26 (Sugiyono, 2018).

Table 4. Interpretation of the value of the $r_{i}$

\begin{tabular}{cc}
\hline Range & Description \\
\hline $0,90<\mathrm{r}_{\mathrm{i}} 1,00$ & Very high \\
$0,70<\mathrm{r}_{\mathrm{i}} 0,90$ & High \\
$0,40<\mathrm{r}_{1} 0,70$ & Medium \\
$0,20<\mathrm{r}_{\mathrm{i}} 0,40$ & Low \\
$\mathrm{r}_{\mathrm{i}} \leq 0,20$ & Very Low \\
\hline
\end{tabular}

The steps that will be done in the process of learning that. 1) the Researcher explained briefly related the material studied in class IV-B (experimental class) by using the learning model Problem-Based Learning (PBL). 2) the Teacher informs the students through the WhatsApp group to enter the google meet on the link provided 3) the Teacher opens the lesson by giving greetings and pray as well as the supervisor of the learners. 4) the Teacher tells the students to form groups consisting of 4-5 people. 5) Teachers deliver material circumference and area of a square and a rectangle and ask learners about the material. 6) the Teacher ask the problem to the learners to be solved in groups. 7) the Student conduct discussions via a WhatsApp group that has been provided by the teacher to do a video call or chat group together with friends a bunch of those. 8) Teachers observe and help students who have difficulty. 9) the Teacher gives the students the chance to present or present the results of its work through zoom meetings and then conclude. 10) the Teacher provides reinforcement and discussion of the answers are summed up by the students. 11) the Teacher held a reflection.

\section{RESULT AND DISCUSSION}

Result

In the experimental class, students are given learning using PBL models based on google meet with the material of the circumference and area of a square, rectangle, and triangle. While for the control class learning is done with the conventional model but still using google meet. The learning activities in the control class can be seen in figure 1. The test is given at the end of the learning with the number 12 essay question. Then the results of the posttest were analyzed descriptively using SPSS 26 and get the result as the average of the experimental class was 76,25 higher than the control class 62,18 with the middle value of the experimental class of 74.00 and control class by 61,00 . The maximum value of the experimental class is 132, while the control class is 112 and then the minimum value of the experimental class and the control class, namely 24 .

Once it is done the results of the analysis of parametric to test the hypothesis, namely with the terms of the data that is produced is homogeneous and normally distributed. So to do a test of homogeneity and normality test first. Test of homogeneity obtained through the test of Levene Statistic while the normality test using Kolmogorov-Smirnov. Normality test results obtained in the experimental class and the control class has a sig value of 0,200 with Asymp sig. (2-Tailed) of 0.47 and the results of the 
homogeneity test got a sig value of 0.184 . Based on the criteria if the value of sig. $>0.05$, then the sample comes from a population that is normally distributed and homogen however, if the sig. $<0.05$, the sample is not derived from a population that is normally distributed and homogeneous (Y. Sari \& Ulia, 2018). After normality test and homogeneity further test the hypothesis with the help of the program SPSS 26 through the test of Independent Sample Test. The hypothesis in this study H1: There is an influence of the use of PBL models based on google meet towards the ability of mathematical problem-solving in grade IV SDN Rawabadak Utara 11 Pagi. On the criteria of decision-making if the value of the significant $>0.05$, then the null hypothesis (HO) is accepted and the alternative hypothesis (H1) is rejected. If the value is significant $<0.05$, then the null hypothesis (H0) is rejected and the alternative hypothesis (H1) accepted (Magdalena \& Angela Krisanti, 2019). Following the results of t-test Independent Sample Test.
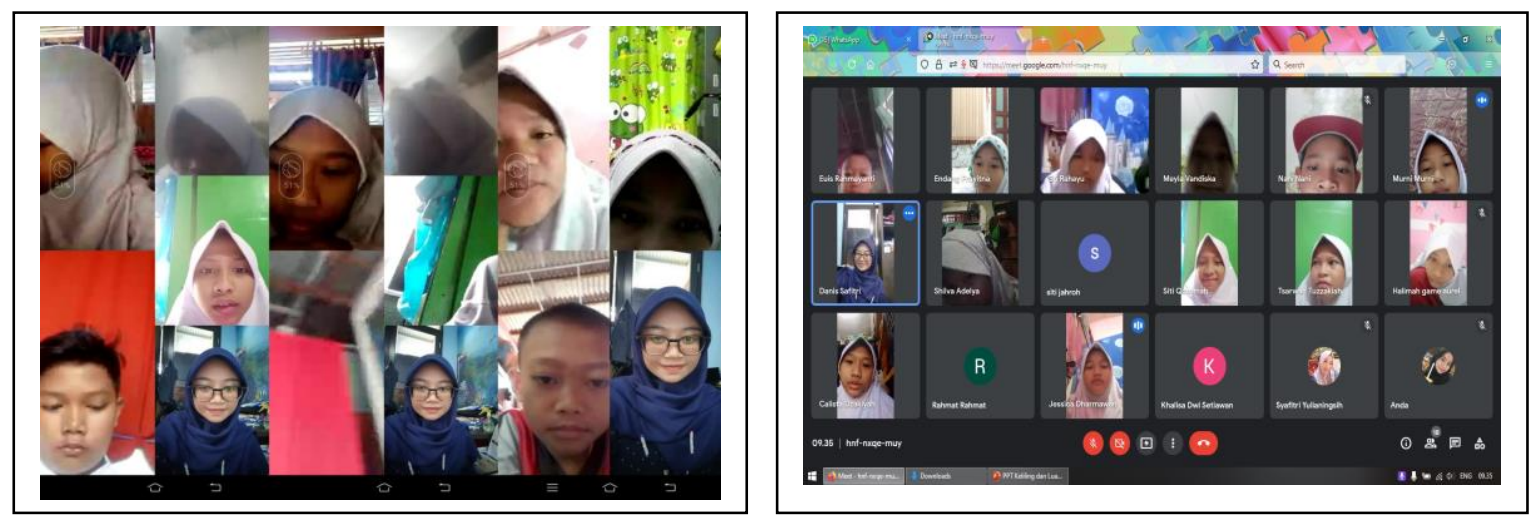

Figure 1. Learning activities-class Experiments

The results of the t-test obtained $t_{\text {count }}$ of 2,027 and have a significant value of 0.47 which means the value is smaller than $\alpha=0.05$. Thus $\mathrm{H} 0$ is rejected, H1 is accepted which means there are no significant results from the ability of mathematical problem solving of students between using the model of Problem Based Learning (PBL) and that do not use a model Problem-Based Learning (PBL) in the SDN Rawabadak Utara 11 Pagi Jakarta Utara. After a hypothesis test will then test the effect size is to measure how influential models of PBL are on problem-solving ability. obtained by calculation using the test effect size of 0,4947 . By the terms and criteria, it can be concluded that the model of PBL have influence is the ability of mathematical problem-solving grade IV.

\section{Discussion}

Based on the results of the research, the use of PBL models based on google meet on the ability of mathematical problem solving has proven effective in enhancing the problem-solving skills because of the model PBL meet the characteristics of student-centred learning to make students more active in participating in learning activities (Lukitasari et al., 2019). The addition of the problems that are often encountered in everyday life will make students able to develop problem-solving skills. In the process of solving the problems, students are allowed to play an active role in learning, searching, and find their information or data to be processed into the concepts, principles, and conclusions (Rahmiati \& Fahrurrozi, 2016). Learners can be said to have the problem-solving ability if learners can perform several stages of the indicators of problem-solving skills such as problem-solving ability is very important in school mathematics, without the ability to solve problems, the usefulness and power of mathematical ideas, knowledge, and skills are very limited (Mariani \& Susanti, 2019; Rambe \& Afri, 2020). As for problemsolving can be used to help students in improving the ability to analyze and positive effect on student learning outcomes (Cahyani \& Setyawati, 2016; Nurliawaty et al., 2017). Of course, optimizing the learning process required a learning model.

In the current conditions is required a variety of learning models are more varied in elementary school (Herliandry et al., 2020; Meilasari et al., 2020). One of them is the model of PBL-based google meet because it is more effective than using conventional learning models on students in primary schools in particular topics chosen and essential in applied mathematics on the learning online (Sugandi \& Bernard, 2020). Learning mathematics with the use of PBL models based on google meet is one of the models that can be used in elementary school to plan for the learning of mathematics fun and meaningful for learners, as well as evoke the initiative or the role of students in exploring the knowledge, thus affecting the improvement of the problem-solving ability of learners (Santika et al., 2020; Sugandi \& Bernard, 2020). Meaningful learning will give the opportunity to students to gain experience and develop social emotions that can later be used in their day-to-day (Bressington et al., 2018; Kostiainen et al., 2018). 
PBL-assisted google meet at a time when online learning makes teachers more flexible in giving the material as it is almost similar to the learning situations at the time of face-to-face so that learning becomes more fun and learning objectives were achieved (Nasution \& Nandiyanto, 2021; Pernantah et al., 2021). Model PBL-based google meet can help the shortage of students in the problem-solving ability. And also can encourage students to learn to work together in small groups to produce thinking skills, able to analyze and solve complex real-world problems (R. M. Hidayati \& Wagiran, 2020). By interacting with peers will be able to reduce the stress of students participating in learning. Learning with peers will encourage learners to take an active role in learning (Oh, 2019). Methods peers improve learning, the learners through the experience that is the feedback from his friend (Gabriele et al., 2016). Peer help, guide and support your fellow peers so that they can build learning through interaction and collaboration (Andersen \& Watkins, 2018). Learning that involves peers will reduce anxiety and stress, with guided, assisted, and are given feedback by their peers, learners will be able to improve self-confidence (Han et al., 2015; Stone et al., 2013). Educators can try to apply the model of PBL-based google meet as an alternative (Harisuddin, 2021; Pernantah et al., 2021). Thus learners and educators can interact with each other in terms of distance learning (distance learning). Educators are expected to encourage learners to be able to learn to think creatively, be active, independent, introduce new ideas, as well as a push to acquire more effective learning so that learning online can be accepted by students as well (Anugrahana, 2020; Kristina et al., 2020).

The results of this study have in common with the previous studies conducted on high SCHOOL students that the model of PBL-based google meet has a greater influence to improve the activity and student learning outcomes for online learning (Djunaedy, 2020). In addition, research is also supported by the research that shows that there is a learning achievement of a high PBL model in the setting of online learning of (Santika et al., 2020). Likewise, research on junior high school students proves that there is the influence of the PBL models online seen from the improvement of learning achievement of the students (Yana et al., 2021). The advantages of PBL models, namely 1) the learners will get used to facing the problem and feel challenged to solve problems, not only related to learning in the classroom, but also in everyday life. 2) Foster social solidarity with the familiar discuss with friends group then discuss with your classmates. 3) Getting to familiarize educators with learners. 4) Familiarize the learners in applying methods of the experiment (Nur et al., 2016; Nuraini \& Kristin, 2017).

While the advantages of the model PBL-based google meet itself is 1) Give students a learning environment that is flexible and constructivist with assisted applications. 2) In the learning environment, students and teachers are freed from the constraints of time and space class. 3) Learning PBL-based google meet to make the interaction and collaboration between students and teachers by allowing them to communicate and collaborate online. 4) Learning potentially provides the opportunity for passive students to participate actively in collaborative problem-solving. 5) the use of models of PBL-based google meet is also encouraging students to be more innovative because students are confronted by a group discussion to analyze. 6) discussion between teachers and learners at the time of presentation of the group focused because each group alternately entered into the room meeting to show the results of the discussion (Lestari et al., 2021; Zakia et al., 2019). The excess of PBL-based google meet can be an alternative solution to improve the ability to solve mathematical problems and activities of the learners because the combination between model pbl and the use of technology in learning has an impact on the process and result of student learning (Harisuddin, 2021; N. Hidayati \& Permana, 2019). In addition to the excess, in this study many factors that make the limitations of the current research as of the less efficient time, the internet network is not stable, the focus of the learners too long, and also it took a lot of internet quota to access google meet. Suggestions for further research can use the wider population and a longer period, as well as the focus of teaching more broadly not only in mathematics as well as cognitive, but using other subjects and other domains. In addition to the refinement of the results of the research, it is better to consider the other factors that allow influencing the process and the results of the study.

\section{CONCLUSION}

Model of problem-based learning (PBL) based on google meet is effectively applied to improve problem-solving skills. online learning that is done is to make students active in the dig and build their knowledge. Therefore, in online learning at this time it takes an innovative learning model that makes the learning process more varied. 


\section{REFERENCES}

Amam, A. (2017). Penilaian Kemampuan Pemecahan Masalah Matematis Siswa Smp. TEOREMA, 2(1). https://doi.org/10.25157/.v2i1.765.

Anazifa, R. D., \& Djukri. (2017). Project- based learning and problem- based learning: Are they effective to improve student's thinking skills? Jurnal Pendidikan IPA Indonesia, 6(2), 346-355. https://doi.org/10.15294/jpii.v6i2.11100.

Andel, S. A., de Vreede, T., Spector, P. E., Padmanabhan, B., Singh, V. K., \& Vreede, G. J. de. (2020). Do social features help in video-centric online learning platforms? A social presence perspective. Computers in Human Behavior, 113(April), 106505. https://doi.org/10.1016/j.chb.2020.106505.

Anugrahana, A. (2020). Hambatan, Solusi dan Harapan: Pembelajaran Daring Selama Masa Pandemi Covid-19 Oleh Guru Sekolah Dasar. Scholaria: Jurnal Pendidikan Dan Kebudayaan, 10(3), 282-289. https: //ejournal.uksw.edu/scholaria/article/view/4033.

Bertan, C. V., Dundu, A. K. T., \& Mandagi, R. J. M. (2016). Pengaruh Pendayagunaan Sumber Daya Manusia (Tenaga kerja) Terhadap Hasil Pekerjaan (Studi Kasus Perumahan Taman Mapanget Raya (Tamara). Jurnal Sipil Statik, 4(1), 13-20.

Bressington, D. T., Wong, W. kit, Lam, K. K. C., \& Chien, W. T. (2018). Concept mapping to promote meaningful learning, help relate theory to practice and improve learning self-efficacy in Asian mental health nursing students: A mixed-methods pilot study. Nurse Education Today, 60(February 2017), 47-55. https://doi.org/10.1016/j.nedt.2017.09.019.

Cahyani, H., \& Setyawati, R. W. (2016). Pentingnya Peningkatan Kemampuan Pemecahan Masalah Melalui PBL untuk Mempersiapkan Generasi Unggul Menghadapi MEA. PRISMA, Prosiding Seminar Nasional Matematika, 151-160.

Dewi, Pratisia, P. (2021). Implementasi pemanfaatan google classroom, google meet, dan instagram dalam proses pembelajaran online menuju abad 21. Jurnal Integrasi Dan Harmoni Inovatif IlmuIlmu Sosial, 1(5), 533-541. https://doi.org/10.17977/um063v1i52021p533-541.

Djunaedy, R. P. (2020). Penerapan Pembelajaran Online dengan Model Problem Based Learning untuk Meningkatkan Keaktifan Belajar Matematika Siswa Kelas XI MM 3 SMKN 5 Malang. Laplace: Jurnal Pendidikan Matematika, 3(2), 95-108. https://doi.org/10.31537/laplace.v3i2.376.

Dong, C., Cao, S., \& Li, H. (2020a). Young children's online learning during COVID-19 pandemic: Chinese parents' beliefs and attitudes. Children and Youth Services Review, 118(August), 105440. https://doi.org/10.1016/j.childyouth.2020.105440.

Dong, C., Cao, S., \& Li, H. (2020b). Young children's online learning during COVID-19 pandemic: Chinese parents' beliefs and attitudes. Children and Youth Services Review, 118(June), 105440. https://doi.org/10.1016/j.childyouth.2020.105440.

Fanny Ahmad Fauzi, \& Puji Lestari. (2020). Implementasi Pembelajaran Individual Head Number Berbasis Google Meet dan Classroom pada Materi Trigonometri. Buana Matematika: Jurnal Ilmiah Matematika Dan Pendidikan Matematika, 10(2), 175-188. https://doi.org/10.36456/buanamatematika.v10i2.2568.

Firman, \& Rahman, S. R. (2020). Pembelajaran Online di Tengah Pandemi Covid-19 Firman1, Sari Rahayu Rahman1. Indonesian Journal of Educational Science (IJES), 2(2), 81-89.

Harisuddin, M. I. (2021). Kemampuan Pemecahan Masalah Matematis Dan Kemandirian Belajar Siswa Dengan Pjj Dimasa Covid-19. Teorema: Teori Dan Riset Matematika, 6(1), 98. https://doi.org/10.25157/teorema.v6i1.4683.

Hashim, S., Masek, A., Abdullah, N. S., Paimin, A. N., \& Muda, W. H. N. W. (2020). Students' intention to share information via social media: A case study of COVID-19 pandemic. Indonesian Journal of Science and Technology, 5(2), 236-245. https://doi.org/10.17509/ijost.v5i2.24586.

Herliandry, L. D., Nurhasanah, N., Suban, M. E., \& Kuswanto, H. (2020). Pembelajaran Pada Masa Pandemi Covid-19. JTP - Jurnal Teknologi Pendidikan, 22(1), 65-70. https://doi.org/10.21009/jtp.v22i1.15286.

Hidayati, N., \& Permana, D. (2019). Assessment of problem solving abilities and student learning activities based on learning tools: The basis of problem based learning development. International Journal of Scientific and Technology Research, 8(11), 453-456.

Hidayati, R. M., \& Wagiran, W. (2020). Implementation of problem-based learning to improve problemsolving skills in vocational high school. Jurnal Pendidikan Vokasi, 10(2), 177-187. https://doi.org/10.21831/jpv.v10i2.31210.

Hwang, G. J., Wang, S. Y., \& Lai, C. L. (2020). Effects of a social regulation-based online learning framework on students' learning achievements and behaviors in mathematics. Computers and Education, 160, 104031. https://doi.org/10.1016/j.compedu.2020.104031. 
Johan Wicaksana, E., Atmaja, P., \& Ayu Muthia, G. (2021). E-Learning Edmodo Dengan Model Pbl Untuk Meningkatkan Minat Belajar Siswa Pada Masa Pandemi Covid-19. Jurnal Pendidikan Biologi, 12(2012), 45-51.

Kkese, E. (2020). McGurk effect and audiovisual speech perception in students with learning disabilities exposed to online teaching during the COVID-19 pandemic. Medical Hypotheses, 144(July), 110233. https://doi.org/10.1016/j.mehy.2020.110233.

Kostiainen, E., Ukskoski, T., Ruohotie-Lyhty, M., Kauppinen, M., Kainulainen, J., \& Mäkinen, T. (2018). Meaningful learning in teacher education. Teaching and Teacher Education, 71, 66-77. https://doi.org/10.1016/j.tate.2017.12.009.

Kristina, M., Sari, R. N., \& Nagara, E. S. (2020). Model Pelaksanaan Pembelajaran Daring Pada Masa Pandemi Covid 19 Di Provinsi Lampung. Idaarah: Jurnal Manajemen Pendidikan, 4(2), 200. https://doi.org/10.24252/idaarah.v4i2.16945.

Lage-Cala, S., Folgueras-Díaza, M. B., Alonso-Hidalgoa, M., García-Menéndezb, D., \& Fernández-Garcíab, F. J. (2020). Investigation of the effectiveness of online learning tools for energy performance certificates preparation. Energy Reports, 6, 609-614. https://doi.org/10.1016/j.egyr.2019.09.034.

Lestari, W., Pratama, L. D., \& Sulistiowati, L. (2021). Menunjang Pembelajaran Matematika Secara Daring The Effectivity Of M-Pbl For Supporting. 3, 35-44.

Liu, Q., Huang, J., \& Zhou, Z. (2020). Self-expansion via smartphone and smartphone addiction tendency among adolescents: A moderated mediation model. Children and Youth Services Review, 119(June), 105590. https://doi.org/10.1016/j.childyouth.2020.105590.

Lukitasari, M., Purnamasari, I., Utami, S., \& Sukri, A. (2019). Blended-Problem-Based Learning: How its impact on students' critical thinking skills? JPBI (Jurnal Pendidikan Biologi Indonesia), 5(3), 425434. https://doi.org/10.22219/jpbi.v5i3.10048.

Magdalena, R., \& Angela Krisanti, M. (2019). Analisis Penyebab dan Solusi Rekonsiliasi Finished Goods Menggunakan Hipotesis Statistik dengan Metode Pengujian Independent Sample T-Test di PT.Merck, Tbk. Jurnal Tekno, 16(2), 35-48. https://doi.org/10.33557/jtekno.v16i1.623.

Mariani, Y., \& Susanti, E. (2019). Kemampuan Pemecahan Masalah Siswa Menggunakan Model Pembelajaran MEA (Means Ends Analysis). Lentera Sriwijaya: Jurnal Ilmiah Pendidikan Matematika. https://doi.org/10.36706/jls.v1i1.9566.

Meilasari, S., M, D., \& Yelianti, U. (2020). Kajian Model Pembelajaran Problem Based Learning (PBL) dalam Pembelajaran di Sekolah. Jurnal Pendidikan Biologi Dan Sains, 3(2), 195-207.

Mishra, D. L., Gupta, D. T., \& Shree, D. A. (2020). Online Teaching-Learning in Higher Education during Lockdown Period of COVID-19 Pandemic. International Journal of Educational Research Open, 100012. https://doi.org/10.1016/j.ijedro.2020.100012.

Muhammad, H., R. Eka Murtinugraha, \& Sittati Musalamah. (2020). Pengembangan Media Pembelajaran ELearning Berbasis Moodle Pada Mata Kuliah Metodologi Penelitian. Jurnal PenSil, 9(1), 54-60. https://doi.org/10.21009/jpensil.v9i1.13453.

Mulyanti, B., Purnama, W., \& Pawinanto, R. E. (2020). Distance learning in vocational high schools during the covid-19 pandemic in West Java province, Indonesia. Indonesian Journal of Science and Technology, 5(2), 271-282. https://doi.org/10.17509/ijost.v5i2.24640.

Nasution, A. R., \& Nandiyanto, A. B. D. (2021). Utilization of The Google Meet and Quiziz Applications in The Assistance and Strengthening Process of Online Learning During The Covid-19 Pandemic. Indonesian Journal of Educational Research and Technology, 1(1), 21-31.

Nofziarni, A., Hadiyanto, H., Fitria, Y., \& Bentri, A. (2019). Pengaruh Penggunaan Model Problem Based Learning ( PBL ) Terhadap Hasil Belajar Siswa Di Sekolah Dasar. Jurnal Basicedu. https://doi.org/10.31004/basicedu.v3i4.244.

Nur, S., Pujiastuti, I. P., \& Rahman, S. R. (2016). Efektivitas Model Problem Based Learning (Pbl) terhadap Hasil Belajar Mahasiswa Prodi Pendidikan Biologi Universitas Sulawesi Barat. Saintifik, 2(2), 133141. https://doi.org/10.31605/saintifik.v2i2.105.

Nuraini, F., \& Kristin, F. (2017). Penggunaan Model Problem Based Learning (Pbl) Untuk Meningkatkan Hasil Belajar Ipa Siswa Kelas 5 Sd. E-Jurnalmitrapendidikan, 1(4), 369-379. https://doi.org/10.1080/10889860091114220.

Nurliawaty, L., Mujasam, M., Yusuf, I., \& Widyaningsih, S. W. (2017). Lembar Kerja Peserta Didik (Lkpd) Berbasis Problem Solving Polya. JPI (Jurnal Pendidikan Indonesia), 6(1). https://doi.org/10.23887/jpi-undiksha.v6i1.9183.

Oyedotun, T. D. (2020). Sudden change of pedagogy in education driven by COVID-19: Perspectives and evaluation from a developing country. Research in Globalization, 2(June), 100029. https://doi.org/10.1016/j.resglo.2020.100029.

Patricia, A. (2020). College Students' Use and Acceptance of Emergency Online Learning Due to COVID-19. 
International Journal of Educational Research Open, 100011. https://doi.org/10.1016/j.ijedro.2020.100011.

Pernantah, P. S., Nova, N., \& Ramadhani, A. S. (2021). Penggunaan Aplikasi Google Meet dalam Menunjang Keefektifan Belajar Daring Masa Pandemi Covid-19 di SMA Negeri 3 Pekanbaru. Pedagogi: Jurnal Ilmu Pendidikan, 21(1), 45-50.

Rahayu, S. (2021). Pengaruh Media Pembelajaran E-Learning Terhadap Hasil Belajar Siswa. Pendidikan, $7(1), 68-73$.

Rahmawati, M., \& Latifah, M. (2020). Penggunaan Gawai, Interaksi Ibu-Anak, Dan Perkembangan SosialEmosional Anak Prasekolah. Jur. Ilm. Kel. \& Kons., 13(1), 75-86. https://doi.org/DOI: http://dx.doi.org/10.24156/jikk.2020.13.1.75 Penggunaan.

Rahmiati, R., \& Fahrurrozi, F. (2016). Pengaruh Pembelajaran Missouri Mathematics Project (Mmp) Terhadap Kemampuan Pemecahan Masalah Matematika. Jurnal Pendidikan Matematika, 10(2), 112. https://doi.org/10.22342/jpm.10.2.3634.75-86.

Rambe, A. Y. F., \& Afri, D. L. (2020). Analisis kemampuan pemecahan masalah matematis siswa dalam menyelesaikan soal materi barisan dan deret. AXIOM : Jurnal Pendidikan Dan Matematika, 09(2), $175-187$.

Rosmiati, U., \& Lestari, P. (2021). Inovasi Model Pembelajaran PBI (Problem Based Instruction) Berbasis Whatsapp Sebagai Langkah Solutif Pembelajaran di Masa Pandemi Covid-19. JNPM (Jurnal Nasional Pendidikan Matematika), 5(1), 188. https://doi.org/10.33603/jnpm.v5i1.3708.

Ruchaedi, D., \& Baehaki, I. (2016). Pengaruh Problem Based Learning (PBL) Terhadap Kemampuan Heuristik Pemecahan Masalah Dan Sikap Matematis Siswa Sekolah Dasar. Jurnal Cakrawala Pendas. https://doi.org/10.31949/jcp.v2i2.331.

Rusli, R., Rahman, A., \& Abdullah, H. (2020). Student perception data on online learning using heutagogy approach in the Faculty of Mathematics and Natural Sciences of Universitas Negeri Makassar, Indonesia. Data in Brief, 29, 105152. https://doi.org/10.1016/j.dib.2020.105152.

Safithri, R., Syaiful, S., \& Huda, N. (2021). Pengaruh Penerapan Problem Based Learning (PBL) dan Project Based Learning (PjBL) Terhadap Kemampuan Pemecahan Masalah Berdasarkan Self Efficacy Siswa. Jurnal Cendekia: Jurnal Pendidikan Matematika, 5(1), 335-346. https://doi.org/10.31004/cendekia.v5i1.539.

Sahu, P. (2020). Closure of Universities Due to Coronavirus Disease 2019 (COVID-19): Impact on Education and Mental Health of Students and Academic Staff. Cureus, 2019(4), 4-9. https://doi.org/10.7759/cureus.7541.

Samaha, M., \& Hawi, N. S. (2016). Computers in Human Behavior Relationships among smartphone addiction, stress, academic performance, and satisfaction with life. Computers in Human Behavior, 57, 321-325. https://doi.org/10.1016/j.chb.2015.12.045.

Santika, I. W. D., Parwati, N. N., \& ... (2020). Pengaruh Model Pembelajaran Berbasis Masalah Dalam Setting Pembelajaran Daring Terhadap Prestasi Belajar Matematika dan Kemampuan Pemecahan Masalah .... ... Pembelajaran ..., X, 105-117. https://doi.org/10.23887/jtpi.v10i2.3397.

Sari, E. P., \& Sukardi, S. (2020). Optimalisasi Penggunaan E-learning dengan Model Delone dan McClean. Journal of Education Technology, 4(2), 141. https://doi.org/10.23887/jet.v4i2.24819.

Sari, K. A., Lusa, H., \& Yusuf, S. (2017). Perbedaan Hasil Belajar Dengan Menggunakan Strategi Pemanfaatan Perpustakaan Sekolah Sebagai Sumber Belajar Siswa Sdn Kota Bengkulu. Jurnal PGSD, 10(2), 99-106. https://doi.org/10.33369/pgsd.10.2.99-106.

Sari, Y., \& Ulia, N. (2018). Efektivitas Bahan Ajar Komik IPA terhadap Hasil Belajar Siswa Kelas V Sekolah Dasar. Jurnal Ilmiah Pendidikan Guru Sekolah Dasar, 2(2).

Shofiyah, N., \& Wulandari, F. E. (2018). Model Problem Based Learning (Pbl) Dalam Melatih Scientific Reasoning Siswa. Jurnal Penelitian Pendidikan IPA, 3(1), 33. https://doi.org/10.26740/jppipa.v3n1.p33-38.

Sugandi, A. I., \& Bernard, M. (2020). Efektivitas Pembelajaran Daring Berbasis Masalah Berbantuan Geogebra Terhadap Kemampuan Penalaran Matematis Di Era Covid-19 IKIP Siliwangi , Cimahi , Jawa Barat, Indonesia 9(4), 993-1004.

Sugiyono. (2018). Metode Penelitian Kuantitatif, Kualitatif, dan R \& D. Alfabeta.

Suhartono, S. (2018). Mengajarkan Pemecahan Masalah Matematika di Sekolah Dasar. Matematika Dan Pembelajaran. https://doi.org/10.33477/mp.v6i2.671.

Suhery, S., Putra, T. J., \& Jasmalinda, J. (2020). Sosialisasi Penggunaan Aplikasi Zoom Meeting Dan Google Classroom Pada Guru Di Sdn 17 Mata Air Padang Selatan. Jurnal Inovasi Penelitian, 1(3), 129-132. https://doi.org/10.47492/jip.v1i3.90.

Tambunan, L., Rusdi, R., \& Miarsyah, M. (2018). Efectiveness of Problem Based Learning Models by Using E-Learning and Learning Motivation Toward Students Learning Outcomes on Subject Circullation 
Systems. Indonesian Journal of Science and Education, 2(1), 96. https://doi.org/10.31002/ijose.v2i1.598.

Usman, F. A., \& Afriansyah, E. A. (2017). Kemampuan Pemahaman Matematis Siswa Melalui Model Pembelajaran Auditory Intellectualy Repetition Dan Problem Based Learning (Studi Penelitian di SMP Negeri 1 CisurupanKelas VII). Jurnal Pendidikan Matematika, 11(1), 68. https://doi.org/http://dx.doi.org/10.22342/jpm.11.1.3890.67-78.

Yana, R. L., Ayatusa'adah, A., \& Nirmalasari, R. (2021). Penerapan model problem based learning secara daring terhadap keaktifan dan prestasi belajar biologi peserta didik. Journal of Biology Learning, 3(1), 18. https: //doi.org/10.32585/jbl.v3i1.1335.

Yusup, F. (2018). Uji Validitas dan Reliabilitas Instrumen Penelitian Kuantitatif. Jurnal Tarbiyah : Jurnal Ilmiah Kependidikan, 7(1), 17-23. https://doi.org/10.18592/tarbiyah.v7i1.2100.

Zakia, A. R., Djamahar, R., \& Rusdi, R. (2019). Pengaruh Pembelajaran Berbasis Masalah Menggunakan Media Sosial E-Learning Terhadap Hasil Belajar Siswa Sekolah Menengah Pada Sistem $\begin{array}{lllll}\text { Pencernaan. JPBIO } & \text { (Jurnal Pendidikan }\end{array}$ https://doi.org/10.31932/jpbio.v4i1.395. 